\title{
Kaempferia galanga L. Rhizome As a Potential Dental Plaque Preventive Agent
}

\author{
Triana Hertiani", Sylvia Utami Tunjung Pratiwi, Iramie Duma Kencana Irianto, \\ Aini Febriana \\ Faculty of Pharmacy, Universitas Gadjah Mada, \\ Sekip Utara, Yogyakarta 55281 INDONESIA \\ Faculty of Pharmacy, UGM, Yogyakarta, Indonesia,
}

\begin{abstract}
Dental plaque prevention can be achieved by inhibition of mouth cavity microbes to built biofilm. Kaempferia galanga rhizome has been known as a potential antibacterial agent. This research aimed to reveal the potency of Kaempferia galanga extract and essential oil as anti plaque active agents, based on their in vitro inhibitory activity against the planktonic growth and biofilm of Streptococcus mutans ATCC 21752. Kaempferia galanga extract was obtained by defatting dried-pulverized samples in petroleum ether prior to immersion in $70 \%$ ethanol. The fresh rhizome was steam-hydro distilled for $6 \mathrm{~h}$ to yield the essential oil. Antibacterial and anti biofilm assays were measured by micro dilution technique on polystyrene 96-wells micro titer plates at $37^{\circ} \mathrm{C}$. The percentage of inhibition was calculated by comparing the absorbance of samples to the vehicle (control) measured by micro plate reader at $595 \mathrm{~nm}$. Biofilms formed were first stained by $1 \%$ crystal violet. The above assays were performed in triplicates. This study revealed that both $K$. galanga rhizome essential oil and ethanolic extract showed antibacterial and antibiofilm activity towards S. mutans. The ethanol extract showed $\mathrm{MIC}_{90}$ value at $0.091 \% \mathrm{w} / \mathrm{v}$ and $\mathrm{MBC}$ at $2.724 \% \mathrm{w} / \mathrm{v}$ for antibacterial activity; IC 50 at $0.048 \% \mathrm{w} / \mathrm{v}$ for anti biofilm formation activity; and $\mathrm{EC}_{50}$ at $0.052 \% \mathrm{w} / \mathrm{v}$ for biofilm degradation activity. Until the highest concentration tested $(0.6 \% \mathrm{w} / \mathrm{v})$, the $\mathrm{MIC}_{90}$ and $\mathrm{MBC}$ values of the essential oil were not revealed, but higher biofilm inhibitory activity i.e. IC $\mathrm{C}_{50}$ at $0.025 \% \mathrm{w} / \mathrm{v}$; and $E_{50}$ at $0.034 \% \mathrm{w} / \mathrm{v}$ were observed.
\end{abstract}

Keywords: biofilm inhibitor, antibacterial, Kaempferia galanga

\section{INTRODUCTION}

Dental plaque is mouth cavity health-related problem caused by biofilm formation. $S$. mutans is a Gram positive bacterium which is frequently found in dental biofilm (Loesche, 2006). It is known to initiate the biofilm formation in tooth surface and has cariogenic properties by demineralizing the enamels (Marsh, 2006). Accumulation of this plaque biofilm will lead to gingivitis and carries which further can lead to dental loss (Marsh, 2006).

The term biofilm itself refers to a collection of adhered cells and their products on a surface (Characklis and Cooksey, 1983). It has been generally accepted that the adsorption of organic layer onto the surface in the aqueous milieu is the first step in biofilm formation (Cooksey and Wigglesworth-Cooksey, 1995). This kind of adsorption which involves electrostatic and hydrophobic interactions between saliva-coated tooth surfaces and pathogenic bacteria suggests the use of chemical agents as part of a plaque-control routine (Ouhayoun, 2003).

Our preliminary screening on several Indonesian herbal extracts revealed $K$. galanga rhizome as a potential antibacterial and anti biofilm towards S. mutans (Hertiani et al., 2010). This rhizome itself has been widely used either as part of spices or as traditional medicine e.g., analgesic, expectorant, diuretic etc. (Faroug et al., 1995).

The methanol extract was reported to expose antibacterial activity towards Staphylococcus aureus, Escherichia coli and Candida albicans (Taswin, 1994).

*Corresponding author email : hadna3ana@yahoo.com 
This study aimed to reveal the potency of Kaempferia galanga rhizome as a potential dental plaque preventive agent. The essential oils and ethanol extract will be then evaluated for their inhibitory activity against planktonic growth, biofilm formation and adherence of S. mutans.

\section{METHODOLOGY}

\section{Plant materials}

Fresh rhizomes of Kaemferia galanga L. were collected on February, 2009 in Yogyakarta, Indonesia. The species was identified by Mr. Joko Santoso (Pharmacognosy Laboratory, Faculty of Pharmacy, UGM) under register number FA/BF/Ident./VIII/2009.

Fresh samples were separated into two different treatments to yield the essential oil and the ethanol extract. The essential oil was obtained by steam-hydro distilled the fresh samples for $6 \mathrm{~h}$. Ethanol extract was obtained by defatting the dried pulverized samples in petroleum ether, prior to immersion in $70 \%$ ethanol. The macerated were collected and evaporated to yield the ethanol extract.

Microbial strain used was Streptococcus mutans ATCC 21752 obtained from Inter University Centre-Food and Nutrition, UGM, Yogyakarta, Indonesia.

\section{Bacteria and Culture condition}

Bacteria were grown in nutrient broth for 24 $\mathrm{h}$ at $37^{\circ} \mathrm{C}$. A McFarland standard 2 was used to obtain inoculums density in $\mathrm{NaCl}$ solution (MIC assays). Bacteria used in biofilm assays were grown in BHI enriched with sucrose $2 \%$, and the inoculums density was adjusted to McFarland standard 5 for anti biofilm assays.

\section{Equipments}

Biorad $\AA$ Benchmark micro plate reader (Tokyo, Japan), TLC chamber, UV lamps 254 and $366 \mathrm{~nm}$, micropipettes Socorex ${ }^{\circledR}$ (single channel: 0.5-10; 5-50; 50-200, 200-1000 $\mu \mathrm{L}$; multi channel $20-200 \mu \mathrm{L}$ ), autoclave; drying oven 40 $60^{\circ} \mathrm{C}$; micro titer plate flat-bottom and flexible Ubottom PVC 96 wells; incubator; Laminar Air Flow chamber.

\section{Determination of the minimum Inhibitory concentration (MIC 90 )}

MICs were determined by modified micro titer broth method in sterile flat bottom 96-well polystyrene plates (Amsterdam, 1996). Serial dilution techniques were used to determine the MICs of samples after $24 \mathrm{~h}$ growth at $37^{\circ} \mathrm{C}$. DMSO were used to dilute the ethanol extracts while the essential oils were diluted in metanol. Negative controls (cells + media), positive control (cells + media + mouthwash product "L"), vehicle controls (cells + media + metanol/DMSO), and media controls were included. Blank samples were prepared as samples but without cells added. All tests were performed at least in triplicate. Optical density readings were taken using micro plate reader at $595 \mathrm{~nm}$ for $24 \mathrm{~h}$ post-inoculation. Percentages of inhibitions were calculated using formula as follows:

$$
\% \text { Inhibition }=\left(1-\left(\frac{\text { ODsample-ODsample blank }}{\text { ODvehicle-ODvehicle blank }}\right)\right) \times 100 \%
$$

(modified from Quave et al., 2008)

\begin{abstract}
Note: $O D_{\text {sample: }}$ Optical Density of samples + bacterial suspension; $O D_{\text {sample-blank: Optical Density of samples }}$

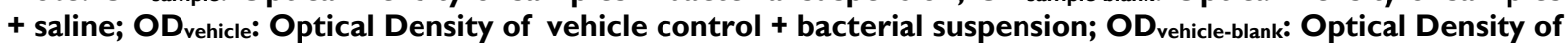
vehicle control + saline. MIC 90 values determined as the lowest concentration required to inhibit at least $90 \%$ of inhibition.
\end{abstract}

Samples mixtures were re-inoculated on Nutrient Agar plates. MBC value was determined as the lowest concentration with no growth occurred on Agar plates (Rasooli et al., 2008).

\section{Determination of the biofilm formation inhibition $\left(\mathrm{IC}_{50}\right)$}

$\mathrm{IC}_{50} \mathrm{~s}$ were determined by the adherence assay in flexible U-bottom 96-well plates (modified from O'Toole and Kotter, 1998). A similar serial dilution was as performed in antibacterial assay. After $24 \mathrm{~h}$ incubation, the supernatants were aspired from the wells, rinsed 3 times with distilled water, and fixed for $10 \mathrm{~min}$. Then, $200 \mu \mathrm{L}$ of $1 \%$ crystal violet was added to the wells and left for $15 \mathrm{~min}$ to stain the formed biofilm. The excess stain was rinsed off with tap water, followed by addition of $200 \mu \mathrm{L}$ of methanol to the wells and transfer to a flat bottom 96-well 
plate. Optical density readings were taken using micro plate reader at $595 \mathrm{~nm}$. Inhibition percentages were calculated using formula (1). $\mathrm{IC}_{50}$ is concentration of samples which showed $50 \%$ inhibition in comparison to vehicle controls and calculated by using probit analyses.

\section{Determination of the biofilm degradation activity $\left(\mathrm{EC}_{50}\right)$}

$\mathrm{EC}_{50} \mathrm{~S}$ were determined by the adherence assay in flexible U-bottom 96-well polystyrene plates as performed on biofilm formation inhibition assay (modified from O'Toole and Kotter, 1998). After $24 \mathrm{~h}$ incubation of bacteria suspension in media used (without samples), the supernatants were aspired from the wells. A serial dilution of samples in media were then added to the wells and incubated for another $24 \mathrm{~h}$ in $37^{\circ} \mathrm{C}$. Further treatments were as performed on the biofilm formation inhibition assay. $\mathrm{EC}_{50}$ is concentration of samples which showed 50\% biofilm degradation activity in comparison to vehicle controls and calculated by using probit analyses.

\section{Bioautography (Gibbons and Gray, 1998)}

Several TLC systems were evaluated to find out the best separation of the sample components. After drying the suitable eluents, one eluted TLC plate was put on to the Nutrient Agar containing bacteria in petri dish for $30 \mathrm{~min}$, while others were evaluated under UV lamps 254 and $366 \mathrm{~nm}$, and sprayed with anisaldehyde $\mathrm{H}_{2} \mathrm{SO}_{4}$ and $\mathrm{FeCl}_{3}$ separately. After incubation in $37^{\circ} \mathrm{C}$ for $24 \mathrm{~h}$, the diameter of inhibition zones of each spots were measured in $\mathrm{mm}$.

\section{RESULTS}

The ethanol extract yielded in this study was $4.98 \% \mathrm{w} / \mathrm{w}$ of dried samples, while the essential oil was $0.18 \% \mathrm{v} / \mathrm{w}$ of fresh samples. Result of the anti bacterial and anti biofilm assays showed dose dependant manner (Fig.1 and 2). Nevertheless, the essential oil showed planktonic growth inhibitory percentage $73.99 \%$ at $0.6 \% \mathrm{v} / \mathrm{v}$ but at a higher concentration tested $(1.2 \% \mathrm{v} / \mathrm{v})$, dose dependant respond was no longer observed. This may be due to low solubility of the essential oil in media. At the lowest concentration used, no inhibition observed as could be seen by the negative values as the result of inhibition percentage calculation. Low concentration of active compounds might not sufficient to show inhibitory activity; on the other hand, other compounds which supported the growth might have chance to exhibit their influences.

Results summary of the antibacterial and anti biofilm assays is as described in table I. The results showed that the ethanol extract was more potent as antibacterial agent with $\mathrm{MIC}_{90}$ value at $0.091 \% \mathrm{w} / \mathrm{v}$ and $\mathrm{MBC}$ at $2.724 \% \mathrm{w} / \mathrm{v}$ in comparison to the essential oil. On the other hand, the essential oil showed higher antibiofilm activity with $\mathrm{IC}_{50}$ value at $0.025 \% \mathrm{v} / \mathrm{v}$ and $\mathrm{EC}_{50}$ at $0.034 \% \mathrm{v} / \mathrm{v}$ in comparison to the ethanol extract which showed $\mathrm{IC}_{50}$ value at $0.048 \% \mathrm{w} / \mathrm{v}$ and $\mathrm{EC}_{50}$ at $0.052 \% \mathrm{w} / \mathrm{v}$.

The results above is in accordance to our investigation on antibacterial and antibiofilm activity of the extract against Pseudomonas aeruginosa PAO1, and Staphylococcus aureus PCA 165 at extract concentration of $1 \mathrm{mg} / \mathrm{mL}$. It was revealed that the extract inhibited the planktonic growth of $P$. aeruginosa and $S$. aureus with percentage of inhibition $123.4 \%$ and $101.6 \%$, successively, but only $32.1 \%$ and $77.6 \%$ of biofilm formation inhibition were observed (Pratiwi and Hertiani, unpublished data).

Bioautography results of the ethanol extract showed an inhibition zone of spot at hRf 44 (silica gel 60 F 254 precoated, n-hexane: ethyl acetate $(9: 1 \mathrm{v} / \mathrm{v}))$ while the inhibition zone of essential oil was shown by spot at hRf 56 (silica gel $60 \mathrm{~F} 254$ precoated, toluene-ethyl acetate $(93: 7 \mathrm{v} / \mathrm{v})$ ). These spots showed similar properties in the detection methods used, therefore after comparing the hRf values of the active spots in a same TLC system (Fig. 3), it was concluded that the active principle was the same compound, i.e. ethyl para methoxy cinnamate (EPMS, Fig. 4). This conclusion was supported by TLC profile data of EPMS reported by Juniawan (2004) and Mertasari (2003). 


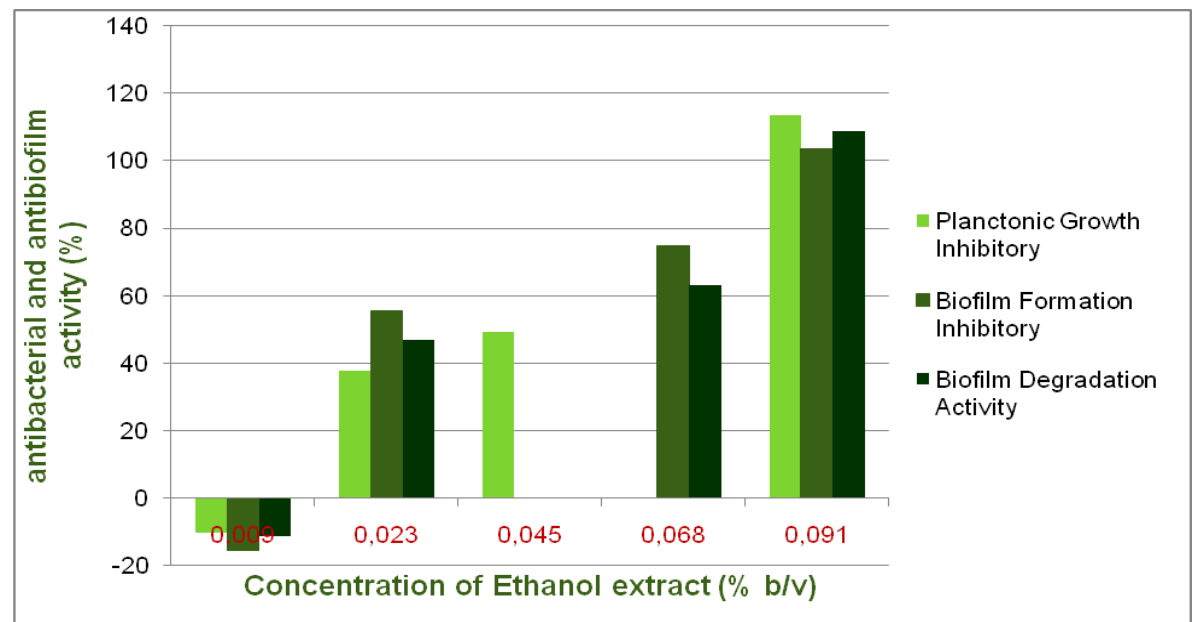

Figure I. Result of antibacterial and anti biofilm activity of the ethanol extract $(n=3)$

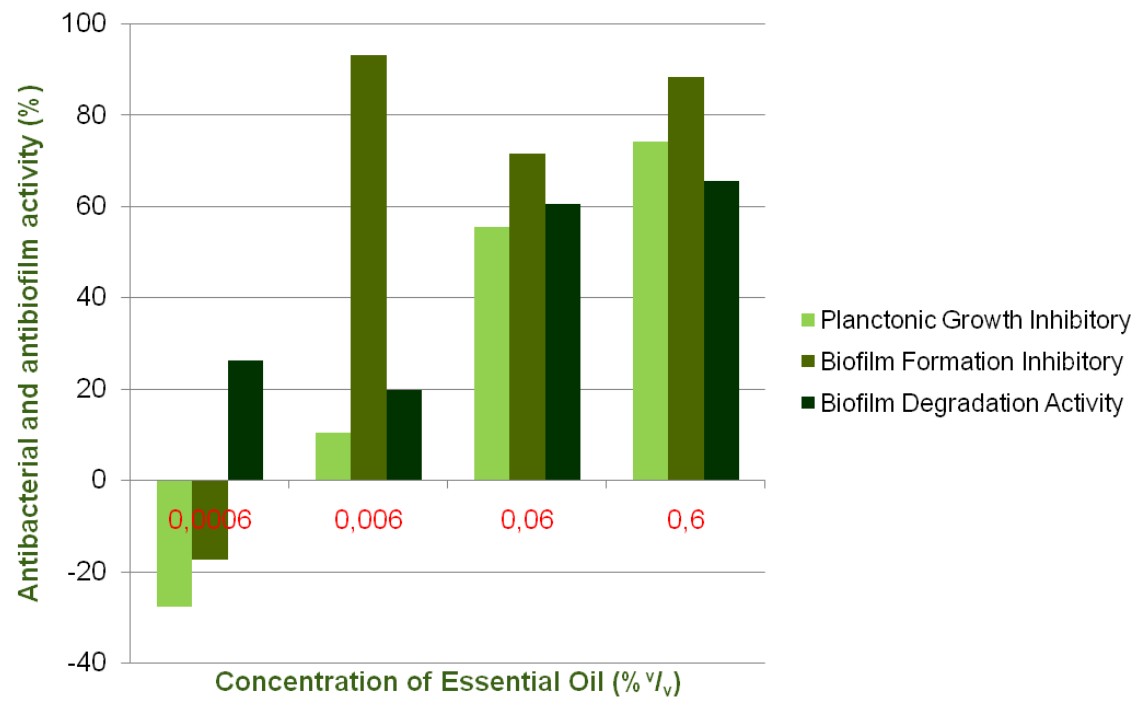

Figure 2. Result of antibacterial and anti biofilm activity of the essential oil $(n=3)$

Table I. Results of antibacterial and anti biofilm assay of $K$. galanga rhizome towards $S$. mutans

\begin{tabular}{ccc}
\hline Assay parameter & Essential oils & Ethanol extracts \\
\hline MIC90 & $>0.6 \% \mathrm{v} / \mathrm{v}$ & $0.091 \% \mathrm{w} / \mathrm{v}$ \\
$\mathrm{MBC}$ & $>0.6 \% \mathrm{v} / \mathrm{v}$ & $2.724 \% \mathrm{w} / \mathrm{v}$ \\
$\mathrm{IC}_{50}$ & $0.025 \% \mathrm{v} / \mathrm{v}$ & $0.048 \% \mathrm{w} / \mathrm{v}$ \\
$\mathrm{EC}_{50}$ & $0.034 \% \mathrm{v} / \mathrm{v}$ & $0.052 \% \mathrm{w} / \mathrm{v}$
\end{tabular}



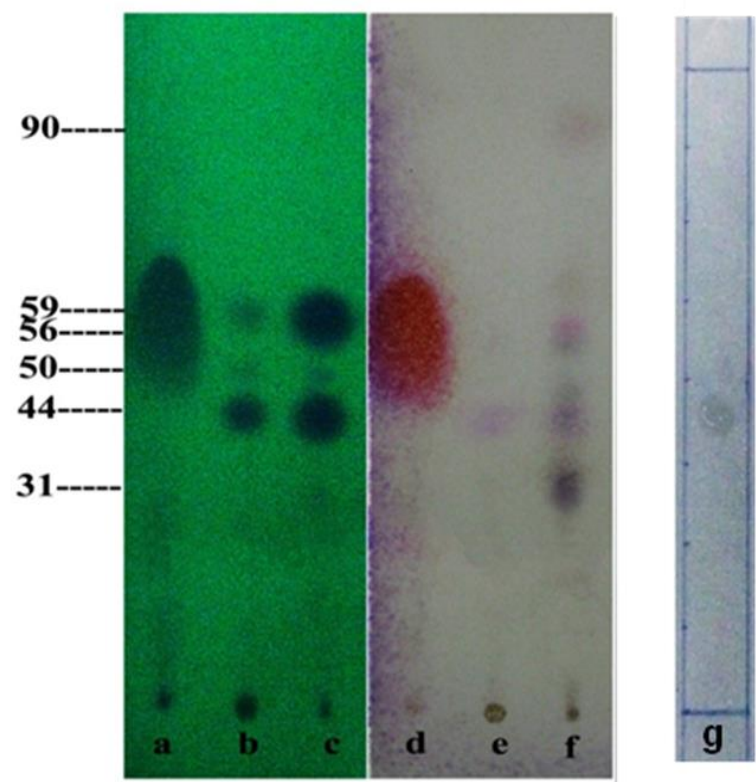

Figure 3. Comparison study of ethanol extract and essential oil TLC profile Note: stationary phase: silica gel 60 F$_{254}$ precoated (Merck, Germany), mobile phase: $n$-hexane:ethyl acetate (9:I v/v); a \& d: thymol; b \& e:ethanol extract; c \& f: essential oil; g: bioautography result on Agar plate with TLC plate as background

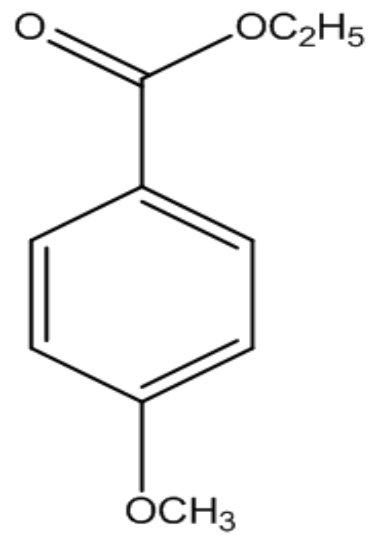

Figure 4. Ethyl p-metoxy cinnamate (BPOM RI, 2004)

\section{DISCUSSION}

It is interesting to note that even though both essential oil and ethanol extract of $K$. galanga possess the active content, EPMS, different potencies observed. This might be due to different concentration of the active compound inside samples. Ethanol was reported by Riyanto (1986) and Taufikkurohmah (2008) as an effective solvent to extract EPMS from $K$. galanga rhizome. On the other hand, Tewtrakul et al., (2004) reported that the major component of essential oil of $K$. galanga rhizome was EPMS (31.77\%). Considering higher antibacterial activity of the extract, it is expected that EPMS content in the ethanol extract was higher than that in the essential oil. The fact that higher anti biofilm activity of the essential oil was observed, it is suggested that other compounds might contribute to this activity. This is in accordance to the result obtained from the TLC profile comparison study of both samples showing more spots detected in the essential oil (Fig. 3). 
Based on the above results, ethanol $96 \%$ utilization without prior defatting process is recommended as the solvent extraction for $K$. galanga rhizome in order to yield active ingredients for oral hygiene product. This kind of extract is expected to have higher amount of EPMS, and in the same time would also contain the essential oil compounds. Therefore higher antibacterial and anti biofilm activity could be obtained. Further investigation would be of course needed to ensure the results.

\section{CONCLUSION}

This study revealed that both $K$. galanga thizome essential oil and ethanol extract showed antibacterial and antibiofilm activity towards $S$. mutans. The ethanol extract was more potent as antibacterial agent in comparison to the essential oil. On the other hand, the essential oil showed higher antibiofilm activity. Compound responsible for antibacterial activity was ethyl para methoxy cinnamate.

\section{ACKNOWLEDGMENT}

This research was part of Bachelor thesis of I.D.K. Irianto and A. Febriana (Faculty of Pharmacy, UGM, Supervisor: T. Hertiani) and partly financed by Hibah Penelitian Berkualitas Prima Faculty of Pharmacy, UGM 2008 No. UGM/FA/606a/M/05/01.

\section{REFERENCES}

Amsterdam, D. 1996, Susceptibility testing of antimicrobials in liquid media. In: Antibiotics in Laboratory Medicine, 52-1II, V., Lorian, $4^{\text {th }}$ Ed., Baltimore: Williams \& Wilkins, MD.

BPOM RI, 2004, Monografi Ekstrak Tumbuhan Obat Indonesia, Vol. I, 46. Jakarta, Badan Pengawas Obat dan Makanan RI.

Characklis, W.G. and Cooksey, K.E. 1983, Biofilms and microbial fouling. In: Applied Microbiology, 93-138, A.l., Laskin. New York: Academic Press.

Cooksey, K.E. and Wigglesworth-Cooksey, B. 1995, Aquatic Microbial Ecology, 9, 87-96.

Faroug., H.D., E., Limengka, M.A., Mardiaty, S., Nurhayati, Rosita, Sjahrir, and U., Syamsudin, 1995, Informasi Simplisia Asing, 45-46, Jakarta: Departemen Kesehatan Republik Indonesia.
Juniawan, H. 2004. Formulasi Tablet Effervesent Ekstrak Kencur (Kaempferia galanga) dengan Variasi Jumlah Asam Sitrat - Asam Tartrat. Bachelor Thesis. Yogyakarta: Universitas Gadjah Mada, Faculty of Pharmacy.

Hertiani, T., S.U.T., Pratiwi, M., Herianto, and A., Febriana. 2010. Effect of some selected herbal plant extracts as potential dental plaque biofilm inhibitors. Proceeding of International Conference on Medicinal Plants. Surabaya: Universitas Widya Mandala.

Loesche, W.J. 1996. Microbiology of Dental Decay and Periodontal Disease. In: Baron's Medical Microbiology, Baron, S., $4^{\text {th }}$ Ed., Galveston, University of Texas, Medical Branch.

Marsh, P. 2006. Dental plaque as a biofilm and a microbial community-implications for health and disease. BMC Oral Health, 6 (Suppl. I): SI4.

Mertasari, M. 2003 Uji Toksisitas Rimpang Kencur (Kaempferia galanga L.) terhadap Larva Artemia salina Leech dan Isolasi Senyawa Aktifnya. Bachelor Thesis. Yogyakarta: Universitas Gadjah Mada, Faculty of Pharmacy.

O'Toole, G., and Kolter, R., 1998, Initiation of biofilm formation in Pseudomonas fluorescens WCS365 proceeds via multiple, convergent signaling pathways: A genetic analysis, Molecular Microbiology, 28(3), 449-46I.

Ouhayoun, J.P., 2003, Penetrating the plaque biofilm: impact of essential oil mouthwash, J. Clin Periodontol, 30(Suppl. 5), I0-I2.

Quave, C.L., L.R.W., Plano, T., Pantuso, and B.C., Bennett. 2008. Effects of extracts from Italian medicinal plants on planktonic growth, biofilm formation and adherence of methicillin-resistant Staphylococcus aureus, Journal of Ethnopharmacology, I I8 (3), 4I8-428.

Rasooli, I., Shayegh, S., Taghizadeh, M. and Astaneh, S.D.A., 2008, Phytotherapeutic prevention of dental biofilm formation. Phytother. Res. 22, II62-II67.

Riyanto, S., 1988, Isolasi etil p-metoksisinamat dari kencur dengan pelarut etanol, Laporan Penelitian, Fakultas Farmasi UGM, Yogyakarta.

Riyanto, S. 1988. Isolasi etil p-metoksisinamat dari kencur dengan pelarut etanol, Research Report, Yogyakarta, Univeristas Gadjah Mada, Faculty of Pharmacy. 
Taswin, M., 1994, Uji aktivitas antibakteri dan antifungi dari berbagai fraksi rimpang kencur (Kaempferia galanga $\mathrm{L}$ ) serta isolasi dan identifikasi struktur komponen aktif fraksi metanol. Bachelor Thesis, Yogyakarta: Universitas Gadjah Mada, Faculty of Pharmacy.

Taufikurohmah, T., Rusmini, and Nurhayati, 2008, Pemilihan Pelarut dan Optimasi Suhu pada Isolasi Senyawa Etil Para Metoksi Sinamat (EPMS) dari Rimpang Kencur Sebagai
Bahan Tabir Surya pada Industri Kosmetik. Research Report. Malang: Universitas Negeri Malang, Faculty of Mathematics and Life Sciences.

Tewtrakul, S., Yuenyongsawad, S., Kummee, S. and Atsawajaruwan, L., 2004, Chemical components and biological activities of volatile oil of Kaempferia galanga Linn. Songklanakarin J. Sci. Technol., 27(Suppl. 2), 503-50. 